Kampus 4 Universitas Ahmad Dahlan Jl. Ringroad Selatan, Tamanan, Banguntapan, Bantul

Daerah Istimewa Yogyakarta 55191

Telp. : (0274) 563515 Fax. : (0274) 564604

e-mail : ihtifaz@uad.ac.id

Vol. 2, No. 1, Juni 2019, pp. 1-19

ISSN p:2622-4755 e:2622-4798.

DOI: https://doi.org/10.12928/ijiefb.v2i1.717

\title{
Redefining Consumer Utility in The Perspective of Islamic Economics Framework
}

\author{
Zein Muttaqin ${ }^{1 *}$, Martini Dwi Pusparini2 \\ ${ }^{1}$ Postgraduate Student of Department of Economics, \\ Kulliyah of Economics and Management Sciences, \\ International Islamic University Malaysia \\ ${ }^{2}$ Islamic University of Indonesia, Jalan Kaliurang KM. 14.5, 55584, \\ Yogyakarta, Indonesia \\ *e-mail: zeinmuttaqin@gmail.com
}




\title{
Redefining Consumer Utility in The Perspective of Islamic Economics Framework
}

\author{
Zein Muttaqin'*, Martini Dwi Pusparini² \\ ${ }^{1}$ Postgraduate Student of Department of Economics, Kulliyah of \\ Economics and Management Sciences, International Islamic University \\ Malaysia \\ ${ }^{2}$ Islamic University of Indonesia, Jalan Kaliurang KM. 14.5, 55584, \\ Yogyakarta, Indonesia \\ *e-mail: zeinmuttaqin@gmail.com
}

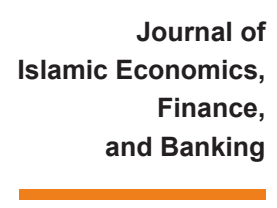

Vol. 2, No. 1, Juni 2019 , pp. 1-19, ISSN p:2622-4755 e:2622-4798

\begin{abstract}
This article aims to redefine the consumer utility in Islamic economics framework. It is embarked from the statement of a well-known Western scholars Milton Friedman that stated that most of western scholars have not succeeded in making clear the definition of utility. In general, utility is individual preferences which can be represented in numerical ways. While others stated it as a matter of subjective feeling that being felt in order to pursue and to maximize the certain level of satisfaction and personal well-being, in which spiritually neutral. On the other hand, most of Muslim scholars argue that spiritual values is important to guide and transform an individual behavior. So that, a Muslim has distinct perception in perceive their satisfaction/well-being which is known as maslahah. The debate on neoclassical and Islamic economics perspectives might contradict one to another, but none of it is at absolute truth, the theory itself is still developing due to different assumptions and circumstances that present at that time. Where the current course of discussion is by revisiting the role of maqasidh al-sharia as the integrated arrays that provide a different view of utility. In summary, this study unfold that Islam has defined utility as the act to seek self-actualization of benefit which collide to the benefit of others in pursuing of enhancement of dual dimensions objectives of present and hereafter. The highlight point that is found in this study is that to pursue maximization of utility -for Muslim- is deemed should consider the possibility of misleading the genuine motive of utility, which is not adjusting it under social pressures. The misleading act as such is categorized as the act of falsification of preferences.
\end{abstract}

Keywords: Utility, Consumer Behavior, Microeconomics, Islamic Economics

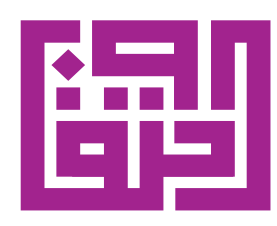




\section{Abstrak}

Artikel ini bertujuan untuk mendefinisikan kembali utilitas konsumen dalam IHTIFAZ - JIEFB kerangka ekonomi Islam. Studi ini berangkat dari pernyataan ilmuwan barat terkenal Milton Friedman yang menyatakan bahwa kebanyakan dari ilmuwan barat masih belum mampu untuk memberikan definisi yang jelas atas istilah utilitas. Dimana secara umum, utilitas merupakan preferensi seorang individu yang dapat direpresentasikan oleh angka-angka atau secara matematis. Disisi lain, banyak yang menyatakan bahwa utilitas sebagai rasa subjektif yamg dirasakan oleh individu untuk mencapai kepuasan maksimal pada titik tertentu yang bersifat personal dan bebas dari nilai-nilai spiritual. Sedangkan, kebanyakan dari ilmuwan Islam berargumentasi bahwa nilai-nilai spiritual adalah penting dalam membimbing dan mentransformasi perilaku individu. Sehingga, seorang Muslim memiliki persepsi yang jauh berbeda dalam menilai kepuasan diri mereka yang biasa dikenal dengan istilah maslahah. Perdebatan antara teori neo-klasik dan ekonomi Islam terkadang bertentangan satu dengan yang lain, namun tidak ada yang namanya kebenaran mutlak, karena teori itu sendiri terus berkembang dengan asumsi dan kondisi yang berbeda terutama sekarang ini. Alur diskusi saat ini adalah mengkaji kembali peran dari maqasidh al-sharia sebagai satuan acu yang terintegrasi dalam memberikan sudut pandang baru tentang utilitas. Studi ini menyimpulkan bahwa Islam mendefinisikan utilitas sebagai tindakan dalam mencari aktualisasi kebaikan diri yang bertemu dengan kebaikan orang lain dalam mencapai peningkatan utilitas dalam dua dimensi, yakni duniawi dan akhirat. Hal utama yang menjadi temuan dalam studi ini adalah dalam mencapai maksimisasi utilitas -untuk Muslim- diharapkan untuk selalu mempertimbangkan kemungkinan dari ketersesatan motif asli dari utilitas itu sendiri yang mana tidak dipengaruhi oleh tekanan-tekanan social. Ketersesatan ini dikategorikan sebagai tindakan pemalsuan preferensi.

Kata Kunci: Utilitas, Perilaku Konsumen, Ekonomi Mikro, Ekonomi Islam

\section{INTRODUCTION}

In middle of economic dynamics around the world and the burst of technology innovations since the presence of globalization in 90's, the market and consumer shift their nature accordingly. This major changes is caused by three factors, they are (i) the shape of the nature competition; (ii) the power market actors; (iii) subsequently consumer orientations and priorities (Ali \& Wisniesk, 2010, p. 36). The consumer as the actor of market has a powerful role in improving the economy. On the other hand, the over-produced product in adjusting to the consumer demand influences consumer behavior. Hence, this leads to the competition of consumer to pursue their needs and wants in fully-satiated orientation.

According to the classical and secular, the very nature of man is selfish (Hassan, 1996). When the terminology of selfish is embarked from the selfish gene that proposed by Richard Dawkins in 1976, he claims that selfish gene is the condition where an individual do not consistently do things for the benefit of others. The act of selfish in the economy is one part of assumptions in defining the term of homo economicus which oriented to maximize their subjective-defined satisfaction. 
The debate of individuals' economic objectives between neoclassic and Islamic economic is far long to the end of conclusion. The main factor that divide between neoclassic and Islamic economic lies in the injunction of Islamic or spiritual values, while most neoclassic agreed upon the industry that spiritually neutral. On the contrary, the injunction of spiritual values (Islamic values) is a part of transformative attempt to the individual to act as they should, rather than as they are (Farooq, 2011; Furqani, 2014).

As mentioned earlier, the end game of consumer behavior objective is by maximizing their satisfaction/utility to the fullest. Islam also recognize the fulfilling role to enhance one's welfare. Nonetheless, the issue of maximizing of utility needs to be addressed further. There is proof of the unclear of defining utility, because of the difference of beginning foothold (Friedman, 1955). The next issues that should be discussed is how utility is differ in the Islamic perspective context, it can be confirmed that Islamic economics also generate different point of assumptions for individual to abide in the Islamic teaching. For instance, even Islamic economic recognize the urge to seek satisfaction of needs, the consumer must abide to the Islamic sources rule, which is to consume moderately and lawfully (i.e. halal or haram). This particular rule also affecting the end game of consumer satisfactions.

Asutay (2007) mentioned that consumer who abide to the Islamic teaching has a dual dimensions of utility, which consists of present utility and hereafter utility. Moreover, Furqani (2014) added that the end game of hereafter utility is a manifestation of falāh. Some of muslim economist, proposed the present utility that should be maximize is known as maslahah, where maslahah or well-being is considered as the main principle of the subsistence of human life. However, the concept of utility and maslahah is different form its philosophical foundation, objective, and means to realize it (Furqani, 2015). In pursuance of better understanding of utility, this article aims to redefine the consumer utility in Islamic economics framework. To reach this goal, this article begins by discussing of motivation, preference and utility in the context of neoclassical perspective. Later then, Islamic consumption theory is revisited as the ground-breaking idea to discuss utility in the Islamic framework. Furthermore, the elaborate discussion of utility in the Islamic economic framework. Then, it concluded in proposing the proper definition of utility in the Islamic economic framework.

\section{MOTIVATION, PREFERENCE, AND UTILITY}

In order to make a decision, consumer is faced by many alternatives of choices. Some people may consider the intrinsic values that manifested from the choices, while some other may consider exterior values rather the intrinsic values of things. In this case, the reason behind such consideration is affected by the motivational nature of 
individual whether they have a perfect information regarding the things that they wish to achieve.

Most of the time, motivation orientations frequently described using the terminology of "selfish" or "altruism" in relating the relationship among others, although these terms almost always have a subjective bias and moral prejudice. Ribal (1962) investigate four possibilities of personality polarity between man and woman consumer to the extends of relative morality on social character, namely (i) altruistic self; (ii) selfish self; (iii) receptive-giving self; (iv) inner sustaining self. All these four personality which driven the motivational forces in understandably by referring to the combination level of succorance (i.e. need to receive) and nurturance (i.e. need to give) (look table 1). In principle, succorance and nurturance is the result of growing desires in man.

Table 1. The Motivation Personality

\begin{tabular}{|c|l|}
\hline \multicolumn{1}{|c|}{ The Altruistic self } & \multicolumn{1}{|c|}{ The Selfish Self } \\
\hline $\begin{array}{l}\text { High needs to give to others } \\
\text { (nurturance -high) } \\
\text { Low needs to receive from others } \\
\text { (succorance-low) }\end{array}$ & $\begin{array}{l}\text { Low needs to give to others } \\
\text { (nurturance-low) } \\
\text { High needs to receive from } \\
\text { others (succorance-high) }\end{array}$ \\
\hline \multicolumn{1}{|c|}{ The Receptive Giving Self } & The Inner Sustaining Self \\
\hline $\begin{array}{l}\text { High needs to give to others } \\
\text { (nurturance-high) } \\
\text { High needs to receive from others } \\
\text { (succorance-high) }\end{array}$ & $\begin{array}{l}\text { Low needs to give to others } \\
\text { (nurturance-low) } \\
\text { Low needs to receive from } \\
\text { others (succorance-low) }\end{array}$ \\
\hline
\end{tabular}

Source: (Ribal, 1962)

In the microeconomic theory, the desire is distinguished into two terms, namely needs and wants. Most of theorist agreed that to distinguish of these two terms must taking into account the limits of desire, which is unlimited. Fundamentally speaking, the unlimited desire that comes to individual is driven by the urge to seek happiness and to relieve or remove one's pain. By then, they instinctively came up with the decision making of the available preference. The deriving of preference that embarked from the individual motivation of fulfilling their desire (i.e needs and wants). The debate on the coexistence of wants and needs in fulfilling individual desire, in some point tends to negate spiritual values for the end of maximize gains. El-ansary (2005, p. 144) stressed that, 
..."economists of different religious affiliations generally appear to accept such neoclassical assertions, because they believe that industrial production processes are spiritually neutral, with all this implies for motivational assumptions and exchange processes, and that the standard analytical tools of neoclassical theory"...

Although, neoclassical agreed that industrial production process are spiritually neutral, it does not implies to affect the enhancement of one's satisfaction or utility.

In general, utility theory is involved with people choice's and decisions (Fishburn, 1968). The decision that would be made by individual is realized in the manner of preference-based approach, hence preference relation. Chipman (1960) emphasized that utility in general form as a lexicographic ordering, represented by finite or infinite dimensional vector with real components. Where Friedman (1955, p. 406) defines "...utility is that property of a thing for a person to which a number is assigned by one another set of operations...". Furthermore, Muflih (2006) mentioned that there are several propositions about utility (Kara, 2012, pp. 181-182), they are:

1. The utility concept in form of material-satiated perceptions.

2. The utility concept affects consumer wants perceptions.

3. The utility concept represents the role of consumer self-interest.

4. Perception of want has purposes to achieve materialistic satisfaction.

5. Self-interest affects consumer material-satiated perceptions.

6. Satisfactory perceptions determine consumer choices.

According to these, there are three major signs of utility, which consists of perception, self-interest, and satisfaction. However, the intrinsic values of utility lies in the term of "pleasure", to quote professor Patten (Pigou, 1903 , p. 58) utility as "...an identification which afforded a theoretical basis for the summation of happiness along the lines of consumers' rent must have been attractive...". Hence, the proper way to address utility in better definition as what has been mentioned by professor Patten in Pigou (1903). Bentham (1822, p. 33-34) elaborates that,

"...The word utility does not so clearly point to the ideas of pleasure and pain as the words happiness and felicity do: nor does it lead us to the consideration of the number, of the interests affected; to the number, as being the circumstance, which contributes, in the largest proportion, to the formation of the standard here in question, the standard of right and wrong, by which alone the propriety of human conduct, in every situation, can with propriety be tried. This want of a sufficiently manifest connexion between the ideas of happiness and pleasure on the one hand, and the idea of utility on the other, I have every now and then found operating, and with but too much efficiency, as a bar to the acceptance that might otherwise have been given, to this principle..." (Sen, 1991, p. 280)

On the same page, Friedman (1955, p. 407) agreed that they have not succeeded in making clear the difference between the definition of 
utility, presumably cause of not sufficiently explicit in pointing out the definition ends and the beginning of hypothesis.

Despite of, the unclear definition of utility, the measurement of utility becomes a relevant issue. According to Fishburn (1968), to understand utility, there are two ways of interpretations, they are, predictive approach, and prescriptive approach. Predictive approach fascinated in the ability of a theory to predict actual choice behavior, when prescriptive approach is fascinated in how individual ought to make a decision. To fully manifested the approaches of interpretation of utility, utility only can be measured referring to the preference relation between goods. This preference that represents the individual choices among goods, which denotes as $\geqslant$, then it can be derived to two other relations, (i) strict preference relation as $>$ for all bundle goods, $\mathrm{x}$ and $\mathrm{y}$ is part of $\mathrm{X}$; (ii) indifference relation as $\sim$ or all bundle goods, $\mathrm{x}$ and $\mathrm{y}$ is part of X (Mas-Colell, Whinston, \& Green, 1995).

Theoretically speaking, in supposed to perceive the preference between goods, the individual should be assumed as a rational consumer. Economic rationality postulates that of all alternative consumptions available for individual, he chooses the one which maximize his gains (Choudhury, 1984). Furthermore, perceiving utility theory is abode to the three categories of assumptions, they are (i) pure existential assumptions; (ii) pure preference assumptions; existential-preference assumptions (Fishburn, 1968, p. 337). First, pure existential assumptions refer to the structure of decision making problem and does not containing preference notations, which means the number of alternative is "finite". Second, pure preference assumptions do not assume the existence of any particular elements in the situation at hands. Third, existentialpreference assumptions mix existence conditions with preferences. These assumptions serve to simplify the structure of individual's preference. In most general assumptions, to consider consumer as a rational consumer and visualize their utility level, there are couple constraint that should be met, which is completeness axiom for every pair of $x, y \in X$ either $y \geqslant x, x \geqslant y$ or both and transitivity axiom for every triple $x, y, z \in X$, if $x \geqslant y$ and $y \geqslant z$, then $x \geqslant z$ (Mas-Colell et al., 1995). However, an interesting point is made by Aumann (1962), that among of all the axioms of utility theory, the completeness axiom is perhaps the most questionable. To quote directly, he said that, "...it is inaccurate as a description of real life; but unlike them, we find it hard to accept even from the normative viewpoint..." and "...it turns out that much of utility theory stays intact even when the completeness axiom is dropped...". Thus, it resulted that there is no longer uniqueness in utility (Aumann, 1962, pp. 446-448). 


\section{ISLAMIC CONSUMPTION RECONSIDERED}

The intuitive thinking and manifesting one's desire to please and maximize their satisfaction is human nature right to the roots. The order to understand of individual problem in the economy context, it is realized to understand the nature of human. The nature of human that is consistently rational and self-interested driven in order to achieve optimum pleasure is known as homo economicus, which introduce by John Stuart Mill in 19's century. However, Johan M. Letiche (1987) argue though mainstream economic theory identifies man behavior with internal consistency of choices and maximize their self-interest, the claim of self-interest maximization yet provide best supposition for man behavior or lead to optimum economic conditions (Hallaq, 1997).

The discussion on how self-maximization progress of homo economicus is encounter by the existence of homo islamicus. Homo islamicus, is assumed as a part of an idealized society, imbued with Islamic values and commitment, which can be claimed to be distinctive from homo economicus (Farooq, 2011, p. 52). The debate of homo economicus and homo islamicus is at the inseminating of spiritual or Islamic values in the economic activities. One thing that is highlighted in the distinct of these human nature, is that homo economicus realized the potential of human by immersing what has been provided around them and often or even negate the spiritual values which hold their desires. When homo islamicus is a heavenly ideal of human that consider all spiritual aspect in their action. This kind of normative issues that emerged in the economy activities, happens to affect one to another in their economy behavior. However, Farooq (2011) emphasized that homo islamicus is based on the norms of Islam in seeks of the existence of human being, which is has strong transformative role. Furthermore, there are subject matter in hand, that should be addressed. Homo economicus has an economic problem of to act "as they are", while homo islamicus has also an economic problem to act "as they should be". These pertaining economic problem has salient features that elaborates by Furqani (2014, p. 171), that shown on the following,
Journal of

Islamic Economics,

Finance,

and Banking

Vol. 2, No. 1, Juni 2019 , pp. 1-19, ISSN p:2622-4755 e:2622-4798 
Table 2. Salient Feature of Economic Problem Subject Matter

\section{IHTIFAZ - JIEFB}

\begin{tabular}{|l|l|}
\hline The Subject Matter & \multicolumn{1}{c|}{ Salient Features } \\
\hline - Economic problems: scarcity of \\
resources and multiplicity of wants. \\
- The focus of study: to analyse the \\
behavior of man in making choices \\
and decisions in resources allocation \\
for needs fulfilment in an Islamic \\
framework. \\
- Target of study: to answer common \\
economic questions of what, how, and \\
for whom to produce (the problem \\
of consumption, production, and \\
distribution) as means to efficiently \\
allocate resources and needs fulfilment. \\
- The nature of discipline: Islamic \\
economics studies how individuals \\
make choices and decisions in the \\
framework of Islamic values and \\
principles and studies its practical \\
impacts. \\
- The objective: human well-being by \\
satisfying all his needs comprehensively
\end{tabular}


Additionally, Asutay (2007) highlight the contrast point between homo economicus and homo islamicus in the following,

Table 3. The Homo Economicus vs Homo Islamicus

\begin{tabular}{|l|l|l|}
\hline & Homo Economicus & Homo Islamicus \\
\hline $\begin{array}{l}\text { The point of } \\
\text { departure }\end{array}$ & $\begin{array}{l}\text { Methodological } \\
\text { individualism }\end{array}$ & $\begin{array}{l}\text { Socio-tropic } \\
\text { individualism }\end{array}$ \\
\hline $\begin{array}{l}\text { Behavioral } \\
\text { postulate }\end{array}$ & $\begin{array}{l}\text { Self-interest oriented } \\
\text { individual }\end{array}$ & $\begin{array}{l}\text { Socially concerned } \\
\text { God-conscious } \\
\text { individual }\end{array}$ \\
\hline $\begin{array}{l}\text { Market } \\
\text { Exchange }\end{array}$ & Pure market exchange & $\begin{array}{l}\text { Islamic imbued } \\
\text { market exchange }\end{array}$ \\
\hline Utility dimension & One dimensional utility & $\begin{array}{l}\text { Dual dimensions } \\
\text { utility }\end{array}$ \\
\hline
\end{tabular}

According to what has been discussed by (Asutay, 2007), the maximization of utility between homo economicus and homo islamicus is distinguished based on the dimensional of utility-percieved. The dual dimension that proposed in the Islamic views is pertaining of present and hereafter satisfying of individual well-being. In accordance to that, Furqani (2014) mentioned the difference of objective of man (look table 2, sub point "the objective"). While homo economicus justified that satisfying of needs comprehensively at present time is better than fullfiling maqāṣid and achieving falās, vice versa. However, the universally applicable theory of human economic behavior, the homo economicus and homo islamicus are one and the same, which in accord to the Quran (Maurer, 2012).

The Islamic consumer behavior is part of the ethical conduct of consumer behavior theory, which inseminated by the Islamic values as its core elements. Generally, in the Western economy, the rational consumer behavior is ethical when: (i) his spending is fairly done even through borrowing,2 (ii) his spending is justified albeit for the appetence desires, (iii) he is not encouraged to borrow even if the bank interest rate is not high, and (iv) he adheres to not spending money in illegal products and services although his spiritual emptiness pushes him/her to acquire the forbidden (Ghassan, 2015, p. 2). In addition, to construct the Islamic consumption theory, there are nine keys of assumptions to be adhered (Hossain, 2014), as follows:

1. Consumer behavior is based on Economic Rationalism and fear of Allah. 
2. A consumer is regarded as economic and moral utility maximize.

3. He can control his wants as well as demand.

4. Utility or Satisfaction derived from worldly (life before death) and Heavenly (life after death) consumption.

5. He only consumes useful while avoid harmful goods and services, for himself and for whole society.

6. Spend in moderation neither as miser nor extravagant, both for here (worldly) and hereafter (Heavenly) life.

7. Strictly consider Halal (legal) and Haram (illegal) in consumption.

8. He does not hoard his wealth.

9. He preferred leading a simple as well as moderate life.

In relate to the previous key assumptions of Islamic consumption theory, Hassan (1996) set three premises as redefining attempt the development of Islamic consumer behavior,

1. A consumer will be assumed to decide what and how to consume in order to fulfil his needs and the needs of his dependents as this is his immediate responsibility.

2. In line with tawhid, a consumer is assumed to consider the welfare of his fellowmen and other creations of Allah from his consumption activity.

3. A consumer will be assumed to always consider consumption as an activity that can lead to the achievement of falāh. This in fact is a rational behavior.

Underpinnings of different philosophical foothold, Muslim's individual have no other alternatives to ideally understand the consumption behavior of Muslims rather than reviewing the real concept of Islamic consumer behavior. Adnan (2011) reviewed four real concept of Islamic consumer behavior that should be revisited, they are:

1. Islamic worldview (tasawwur) perceived as consumption mould

2. Ibadah perceived as consumption method

3. Quality consumption is considered in the act of choice

4. Mechanisms of getting benefits in this world (al-dunya) and hereafter (al-akhirah) become the motivational drive force.

5. His consent (mardhatillah) is regarded as consumption motive/ goals

\section{THE ISLAMIC FRAMEWORK OF UTILITY}

Furqani (2015) proposed that there are three key concept that can be used as alternative to the concept of self-interest, utility, and rationality in the micro-foundation of neoclassical theory, they are huquq, maslahah, and taqwa. 
1. The fundamental relationship of self-interest and huquq

Classical economist stated that human being likes to pursue their own personal interest. Sen (1987, p. 80) describes that "self-interested behavior" structure has three distinct and fundamentally independent merits, namely self-centered welfare, self-welfare goals, self-goal choice. Self-centered welfare, is a state when an individual's welfare only depends on its consumption, whether it involves sympathy or antipathy towards others. Self-welfare goals, is a state where an individual's goal is to maximize its own welfare and given the probability of uncertainty in the weighted of the welfare which does not involve the welfare of others indirectly in the importance manner. Self-goal choice, is a state where each step of individual choices is guided immediately by the pure driven force of pursuing one's own goal in mine, it does not restrain or adapt by the recognition of mutual interdependence of respective success by others. Therefore, self-interest is just a state when individual relies on his own self, driven by himself for the sake of himself.

In Islam, the act of self-interest is recognized as part of human nature, but does not consider it as the absolute concept to explain human behavior. Human tends to get interested in their own curiosity whether something is explainable or not. Huquq has distinct feature than self-interest, huquq can be simplified as act of self-right. Thus, all God's creations have their own role and rights, exclusively to them by certain obligations that revealed in Islamic sources. The concept of huquq could better explain the relationship of man and nature and properly put the ethical foundation in this relationship in an Islamic framework (Furqani, 2015). Furthermore, several concepts may be derived from the distinction of self-interest and huquq, as follows:

1) The concept of self-interest is based on a "unitary self-view", the concept of huquq is based on "holistic and integrated selfview".

2) The concept of self-interest is "unitary and static", in the concept of huquq, it is "reciprocal and dynamic".

3) The concept of self-interest is "one-way" and "static", the process of choice in the concept of huquq is "two-way" and "dynamic".

The process of choice in the concept of huquq is made based on the Islamic consideration of morality (akhlaq), benefit (maslahah) and life hereafter (akhirah), which makes individual self-interest or pleasure as not ultimate/absolute but restricted by other's interest and directed to achieving self-pleasure characterized by having high moral standards and firm spiritual foundations (Furqani, 2015, p. 80).

2. The of utility and maslahah

The optimization of utility function is therefore the origin of the postulate economic rationality, when a consistent set consumer behavior 
is required to affect a well-defined the maximization of utility. There are numerous intense critiques regarding economic rationality. First is IHTIFAZ - JIEFB utilitarianism. Utilitarianism that allegedly inadequate in explaining facts of the political life and the way of states, governments, parties and bureaucracies actually work. Second, the household do not maximizing anything, even though a function is maximized it will be neither consistent nor transitive (Choudhury, 1984, p. 66).

In the Islamic consumer demand theory, ethical consideration in decision making process enter as important consumption bundles of the traditional "non-economic" type. Al-Zarqa (1992) says individual's utility function is treated as an endogenous component of consumption system, thus injunction of spiritual, rituals, guidance, and threats are designed to shift individual utility function to correspond with the true welfare function and also presenting the individual utility function of social welfare. For example, when Muslim went for pray of juma'ah, he donates some of his income to a mosque and not expecting such monetary return. The motivation is highly cause and manifested from his believe, this kind of motivation is categorized as the altruistic-self, according to (Ribal, 1962). The high motive of contribution that driven by the spiritual cause, the Muslim gained an increasing level of utility index that involved the social contract that ultimately shown by the purely egoistic satisfaction. The spiritual injunction is designed to shift an individual utility to coincide with the true welfare function and to make individual's utility an increasing function of social welfare (Al-Zarqa, 1992, p. 105).

In Islamic economic perspective, the postulate of maximization is examined under three aspects (Furqani, 2015, p. 80):

1) In terms of its substantive contents of what is to be maximized; utility or maslahah, pain/pleasure or what is beneficial/harmful?

2) The purpose of maximization; for self-satisfaction/pleasure or self-actualization/ transformation?

3) Instruments or means to achieve them.

On the fundamental level, utility has different philosophy than maslahah. The basis of utility is "individual's wants/desires" and the purpose of utility is "individual's self-satisfaction". On the other hand, the basis of maslahah, on the other hand, is based on the concepts of "beneficial (salah)" and "harm (darar)" (Furqani, 2015, p. 81). However, it need to be fully understand, what is maslahah.

maslahah or wellbeing is considered as the main principle of the subsistence of human life, al-Shatibi classifies maslahah into three categories, dharuriyat (i.e. the essentials are the self-interests upon which people essentially depend, such as faith, life, intellect, posterity, and wealth), hajiyyat (i.e. the complementary interests supplement the essentials and refer to those interests that, if neglected, would lead to 
hardship but not to the total disruption of life's normal order.), tahsinniyat (i.e. the embellishments refer to those interests that, if realized, would lead to refinement and perfection in the customs and conduct of people at all levels of achievement) (Dusuki \& Abdullah, 2007, pp. 32-33).

The associated maslahah as well-being, which equipped with the beneficial values, it must be bounded by some guidelines to accommodate the actual benefit that will be perceived in accordance

Journal of Islamic Economics, Finance, and Banking

Vol. 2, No. I, Juni 2019 , PP. 1-19, ISSN p:2622-4755 e:2622-4798 to the sharia (this in the context of sharia laws) (Al-Mubarak \& Osmani, 2010 , p. 6), the conditions are:

1) Not to contradict an established hukm: when a ruling has been enacted by the Sharia, there can be no maslahah to be considered against it, as the (new) hukm would then be maslahah mulghat.

2) There can be no maslahah to create a new ibadah, nor to add any rukn or shart of any established ibadah, nor to eliminate some parts of any ibadah.

3) Maslahah should be based on a qat'ee (definitive) references, and not zanni (speculative).

4) When a hukm is enacted, the maslahah of that hukm should be greater than the mafsadah of it, neither equal nor less.

5) The maslahah should be a general and inclusive maslahah, not limited and specific to some individual or group.

6) The maslahah should be compatible with the Sharia standards of maslahah, and reasonably understood.

3. The cardinal virtue of rationality and taqwa

Rationality is the cardinal virtue in economics to explain the nature of man, his behavioral patterns and to predict the future outcome of this behavior. It is applied to any entity in the economic realm: the consumer, firm, family and government. Individuals who act according to their self-interest and aim at maximizing their utility, are said to behave rationally (Furqani, 2015).

Generally, Muslim economists prefer to accept the term 'rationality' as it is used in the conventional economic literature but in a different context in order to incorporate Islamic norms and ideals. Siddiqi, in reference to Knight's definition of a rational man as "the man knows what he wants and orders his conduct intelligently with a view to getting it," argues that the assumption of Islamic norms is in no way inconsistent with rationality so defined. He defines a rational Islamic individual as an "individual who would order his behavior with a view to achieve maximal conformity with the Islamic norms." The crux of the matter is that in Islamic economics rational behavior does not necessarily imply maximization(Agil, 1989, p. 89). 
Therefore, instead of saying "Islamic rationality" as the virtue of Islamic man, we found that "taqwa" could be the proper cardinal virtue IHTIFAZ - JIEFB that would perfectly project Islamic ethics in economics and act as a better guide for human behavior. Unlike rationality, taqwa (Rahman, 1999, p. 28) is a proper basis of the ethical relationship of man-God, man-man and man-nature and a "unique balance of integrative moral action that denotes the fully integrated and whole personality of man", hence taqwa is essentially man's God's consciousness (Furqani, 2015).

Hallaq (1997, pp. 25-28) proposes that there are two stages that should be met by consumer (homo islamicus) in order to maximize their ends:

1. The first stage is a state when Muslim individual is willing to offer up his/her life's satisfaction so that his/her consumption obtained gracefully and praiseworthy in expecting God's consent. This state or the rate of substitution of life - satisfaction for Hereafter-praise from God, depends upon his love of God (taqwa). Supposedly that U, P, Y, denotes as the individual's utility function $(U)$ and individual's praise from God $(P)$ and individual's income $(Y)$, it can be written as

$$
U=G(Y, P)
$$

It must be considered that God's praise is an endogenous variables in the Islamic framework.

Later on, assumed that consumer desire to buy various commodity at constant prices, and income is thereby treated as generalized purchasing power, plug into (i). The Rate of substitutions of praise from God $(P)$ for life consumption as:

$$
Y \text { is }-\frac{\delta P}{\delta Y}=\frac{g_{1}}{g_{2}}
$$

however, we must assume that individual income is equal of $r . w=Y$, where $r$ is the wage rates and $w$ is the amount of work performed by the consumer.

If an individual possess the nature of altruistic-self, it would cause high level of taqwa, and it may be assumed that the rate of spending for the sake of God is denoted as (k), such $k>0$. Then, the equation is

$$
U=G(r w, k r w)
$$

since, $Y=r . w$ and $P=k . Y$

to maximize utility, the derivative equation (ii) is conducted with respect to $w=0$.

$$
\begin{gathered}
\frac{\delta U}{\delta W}=g_{1} r+g_{2} k r=0 \\
g_{1} r=-g_{2} k r
\end{gathered}
$$


therefore, the rate of substitutions of praise from God for life consumption is $k$, which states that the rate of substitutions of praise from God $(P)$ for life consumption $(Y)$ equals to the willingness of sacrifice his life's satisfaction ( $k$ ) in order to maximize falah and enrich the hereafter.

2. In the second stage and, assuming that $\mathrm{K}$ or the rate of substitution of life satisfaction for achieving falah in Hereafter is positive $k>0$, we expect that the Muslim individual's income to be $(Y-P)$. Furthermore, since $P=k Y$, we could rewrite his budget constraint as follows: $(Y-k Y) \operatorname{or} Y(1-k)$

Here, if we compare between Muslim and non-Muslim individual, where Muslim will end up with a lower income than the nonMuslim. This applies due to Muslim objective function is differ than non-Muslim, Muslim objective function embodies that his consumption is supposedly to be rewarded in worldly and hereafter, even so the Muslim individual ends up with a lower level of income, he/she actually believed getting more satisfaction that the non-Muslim, since his consumption deed/ satisfaction is merely to pursue God's consent and commendable. In doing so, the Muslim individual needs to maximize his satisfaction by consuming the good (Halal) commodities based upon his budget constraint. The Muslim consumer desires to maximize $U=f\left(q_{1}, q_{2}\right)$ subject to income constraint after $k Y$ spending for the sake of God. Hence,

$$
(Y-k Y)=P, q_{1}+P_{2} q_{2}
$$

The Lagrange function is,

$$
L=f\left(q_{1}, q_{2}\right)+\lambda(Y-k Y)-P_{1} q_{1}-P_{2} q_{2}
$$

where, the marginal utility of income and is assumed to be positive (0), since $M U q_{1}$ and $M U q_{2}>0$.

The necessary conditions for maximizing Muslim's utility function are,

$$
\begin{gathered}
\frac{\delta L}{\delta q_{1}}=f_{1}-\lambda P_{1}=0 \\
\frac{\delta L}{\delta q_{2}}=f_{2}-\lambda P_{2}=0 \ldots \ldots \ldots \ldots \ldots \ldots \ldots \ldots \ldots \ldots \ldots \\
\frac{\delta L}{\delta \lambda}=(Y-k Y)-P_{1} q_{1}-P_{2} q_{2}=0
\end{gathered}
$$

The first two equations (iii, iv) may be written as

$$
\frac{f_{1}}{f_{2}}=\frac{P_{1}}{P_{2}}
$$

This indicates that the ratio of marginal utilities must equal the ratio of prices at maximum and $\frac{f_{1}}{f_{2}}$. This has nothing rather than the rate of commodity substitution (RCS). Therefore, 
the first-order condition for a maximum is expressed by the equality of the (RCS) and the price ratio, which is exactly the same condition for a maximum in the case of the non-Muslim individual. The second-order condition must be satisfactory to a Muslim individual to ensure that a maximum is actually reached.

Based on Hallaq's (1997) study, there are several point to be discussed, first the utility level of consumer is pursuing on two end objectives, which is the maximization of utility at present time and maximization of utility at the future time (i.e hereafter). This ends of objective certainly correspond to what has been discussed by (Asutay, 2007) previously on the existence of duality dimensions of utility. Second, in the commodity market, consumer must abide the purchasing of goods by reflecting to the Islamic lawful system. Islamic lawful system that adhere to the consumption preference does not apply exclusively to the Muslim consumer, but also to the nonMuslim consumer. The pursuance of the good commodity that should be consumed by everyone is benefited non only for Muslims, it also enhance the level of interaction between Muslim and non-Muslims and diminish the exclusivity state in the society. Third, the subjugation of consumer into Islamic teachings, affecting their behavior to become pure altruistic-self and its expected in the model that developed by (Hallaq, 1997). The third point may be found unrealistic, because the very nature of man is not that pure altruist, there will always be a turning point in their inner self. This accordance to the theory of selfish gene and to be reminded that whether it is homo economicus or homo islamicus is a unity of human nature behavior, because Islam does not see self-interest as threat to the individual soul, although it has to be mitigated by imbuing spiritual values together without having to negate one to another. However, we have to believe that the subjugation of Islamic teachings may transform individual to his best version. According to Zaman (2012) the concept of "transformative human beings" is translated as a newborn of individual whom discovered spiritual awareness. Furthermore, Siddiqi (1992, p. 55) emphasized that when a consumer acts under influence of Islamic spirit gives a peculiar tinge to his motivation, he needs to living up his Islamic ideals first. In this sense, living up Islamic ideals supposedly shaped the consumer expectation over desire and satisfaction. Islamic economics present in the actual dynamic phenomenon to explain and transform what has been happened around. It can be stressed that Islamic economic has a mission to straighten and transform the individual's behavior who have abandoned the Islamic values in their actions. The actuality that happens can-not be coerce to the Islamic teaching or vice versa. In the context of the previously discussed of the dilemma of pure altruist-self act, might be consider as a falsification of preference, if it has been coerced to adhere to the Islamic injunctions. 
When people are faced with the decision of how to respond to someone they disagree with, they evaluate the different utilities. Kuran (1997) emphasized that the reality of individual's utility might adept to become the falsification preferences because of the misinterpreting one's genuine wants under perceived social pressures. Furthermore, Kuran (1997) classifies that people evaluate their choices based on three utilitarian factors, they are:

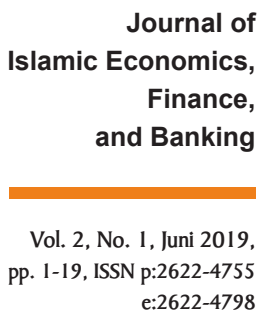

1. Intrinsic utility, is the degree to which an option fulfils the individual's greatest good.

2. Reputational utility, is the amount a certain answer will raise or lower the listener's standing in the community.

3. Expressive utility, is the value in letting others know how one truly feels.

In summation preference falsification occurs when the sum of the three utilitarian factors is highest for alternative that individual privately purposes.

\section{CONCLUSION}

In discussing the nature of man in seeking pleasure and removing pain. The generalized term of utility is "a pleasure" of the portray of "self-interest" nature according to the neoclassical. On the other hand, utility is the Islamic perspective is generalized as "beneficial" of the portray of "self-right" nature, which also known as maslahah. The attempt of redefining utility in the Islamic perspective is concluded as the act to seek self-actualization of benefit which collide to the benefit of others in pursuing of enhancement of dual dimensions objectives of present and hereafter. However, in maximizing the utility function of Islamic economics, it should not be coerced as attempt to be accepted by other opinions. The misleading of coercion of Islamic values in the opposite reality might be led to the falsification of preferences, which is misinterpret under social pressures and harshly regarded as hypocrisy.

\section{REFERENCE}

Adnan, A. A. (2011). Islamic Consumer Behavior (ICB): Its Why And What. International Journal of Business and Social Science, 2(21), 157-165.

Agil, S. O. S. (1989). Rationality in Economic Theory: A Critical Appraisal. Journal of Islamic Economics, 2(2), 79-93. Retrieved from IIUM Islamic Economic Collection Doc No. 730 
Al-Mubarak, T., \& Osmani, N. M. (2010). Applications of Maqasid alShari'ah and Maslahah in Islamic Banking. International Seminar on Islamic Finance, 1-10. http://doi.org/10.13140/RG.2.1.3578.0644

Al-Zarqa, M. A. (1992). A Partial Relationship In A Muslim's Utility Function. In In Readings in Microeconomics: An Islamic Perspective (pp. 105-112). Kuala Lumpur: Longman.

Ali, A. J., \& Wisniesk, J. M. (2010). Consumerism and ethical attitudes: an empirical study. International Journal of Islamic and Middle Eastern Finance and Management, 3(1), 36-46.

Asutay, M. (2007). Conceptualisation of the Second Solution in Overcoming the Social Failure of Islamic Banking and Finance : Examining the Overpowering of Homo Islamicus. IIUM Journal of Economics and Management 15, 15(2), 167-195.

Aumann, R. J. (1962). Utility Theory without the Completeness Axiom. Econometrica, 30(3), 445-462. Retrieved from http://www.jstor. org/stable/1909888

Chipman, J. S. (1960). The Foundations of Utility. Econometrica, 28(2), 193-224. Retrieved from http://www.jstor.org/stable/1907717

Choudhury, M. A. (1984). An Islamic Approach of The Theory of Consumer Demand. Islamic Order Quarterly, 6(3), 66-74. Retrieved from IIUM Islamic Collecction Doc No. 29

Dusuki, A. W., \& Abdullah, N. I. (2007). Maqasid al-Shari'ah. Maslahah, and Corporate Social Responsibility. The American Journal of Islamic Social Sciences, 24(1), 25-44. http://doi.org/10.1007/978-3-64240535-8

El-ansary, W. (2005). The Quantum Enigma and Islamic Sciences of Nature : Implications for Islamic Economic Theory. In The Fifth Conference of the International Association of Islamic Economics (pp. 143-175). Jakarta. Retrieved from https://www.researchgate. net/publication/228373253

Farooq, M. O. (2011). Self-Interest, Homo Islamicus and Some Behavioral Assumptions in Islamic Economics and Finance. International Journal of Excellence in Islamic Banking and Finance, 1(1), 52-79. Retrieved from http://papers.ssrn.com/abstract=1740729\%5Cnhttp://papers. ssrn.com/sol3/papers.cfm?abstract_id=1740729

Fishburn, P. C. (1968). Utility Theory. Management Science, 14(5), 335-378. Retrieved from http://www.jstor.org/stable/2628674

Friedman, M. (1955). What All is Utility? The Economic Journal, 65(259), 405-409. Retrieved from http://www.jstor.org/stable/2227317

Furqani, H. (2014). Economic Problems and the Subject-Matter of Islamic Economics As a Body of Knowledge. In 2nd Asean International Conference on Islamic Finance (pp. 173-183). Yogyakarta. 
Furqani, H. (2015). Individual and society in an Islamic ethical framework: Exploring key terminologies and the micro-foundations of Islamic economics. Humanomics, 31(1), 74-87. http://doi. org/10.1108/H-04-2014-0037

Ghassan, H. B. (2015). Islamic Consumer Model, Fairness Behavior and Asymptotic Utility. Munich Personal RePEc Archive.

Hallaq, S. (1997). Beyond Rationalism: The Role of Values and Emotions In An Islamic Economy. Humanomics, 13(1), 20-39. http://doi. org/10.1108/eb018786

Hassan, N. M. H. N. (1996). Consumer Behavior Theory From Islamic Perspective. IKIM Journal, 4(1), 49-62. Retrieved from IIUM Islamic Economic Collection Doc No. 4603

Hossain, B. (2014). Application of Islamic Consumer Theory: An Empirical Analysis in the Context of Bangladesh. Global Review of Islamic Economics and Business, 2(1), 69-83.

Kara, M. (2012). Pemikiran Al-Syatibi Tentang Maslahah dan Impelementasinya Dalam Pengembangan Ekonomi Syariah. ASSETS, 2(2), 173-184.

Kuran, T. (1997). Private Truths, Public Lies: The Social Consequences of Preference Falsification. United States of America: Harvard University Press.

Mas-Colell, A., Whinston, M. D., \& Green, J. R. (1995). Microeconomic theory. The Canadian Journal of Economics (Vol. 21). http://doi. org/10.2307/135312

Maurer, B. (2012). Re-formatting the economy: Islamic banking and finance in world politics. In Islam in World Politics (pp. 54-66). London: Routledge. http://doi.org/10.4324/9780203356920

Pigou, A. C. (1903). Some Remarks on Utility. The Economic Journal, 13(49), 58-68. Retrieved from http://www.jstor.org/stable/2956866

Ribal, J. E. (1962). The Selfish Self: A Social Psychological Study of Social Character. University of Southern California. Retrieved from http://210.48.222.80/proxy.pac/docview/302160179?account id $=44024$

Sen, A. (1987). On Ethics and Economics. Blackwell Publishing (Vol. 27). Oxford, UK: Blackwell Publishing. http://doi.org/10.2307/2554476

Sen, A. (1991). Utility: Ideas and terminology. Economics and Philosophy, 7(2), 277-283. http://doi.org/10.1017/S0266267100001425

Vol. 2, No. 1, Juni 2019. pp. 1-19, ISSN p:2622-4755 e: $2622-4798$

slamic Economics,

Finance,

and Banking 